\title{
Training and Retaining More Rural Doctors for South Africa
}

\section{By Gail Reed, MS \& Julián Torres}

The guidebooks call Mpumalanga one of the "often overlooked provinces" of South Africa.[1] Northeast of Johannesburg, its grassy hills are just a blur on the highway for foreign visitors heading to the spectacular game reserves of Kruger National Park. They will not often get to Themba Hospital in White River, just 50 miles from the border with Mozambique, serving over three million of Mpumalanga's overwhelmingly rural population.

Themba - which means 'hope' in Swazi - is indeed the hospital of last resort for most of these people, considered among the poorest in the country. The public facility's over 600 beds make it the largest of the province's 32 hospitals. In South Africa, like much of the developed world, the clinics and hospitals exist: the fundamental problem is finding and keeping the health professionals and staff, who are so desperately needed, to run them.

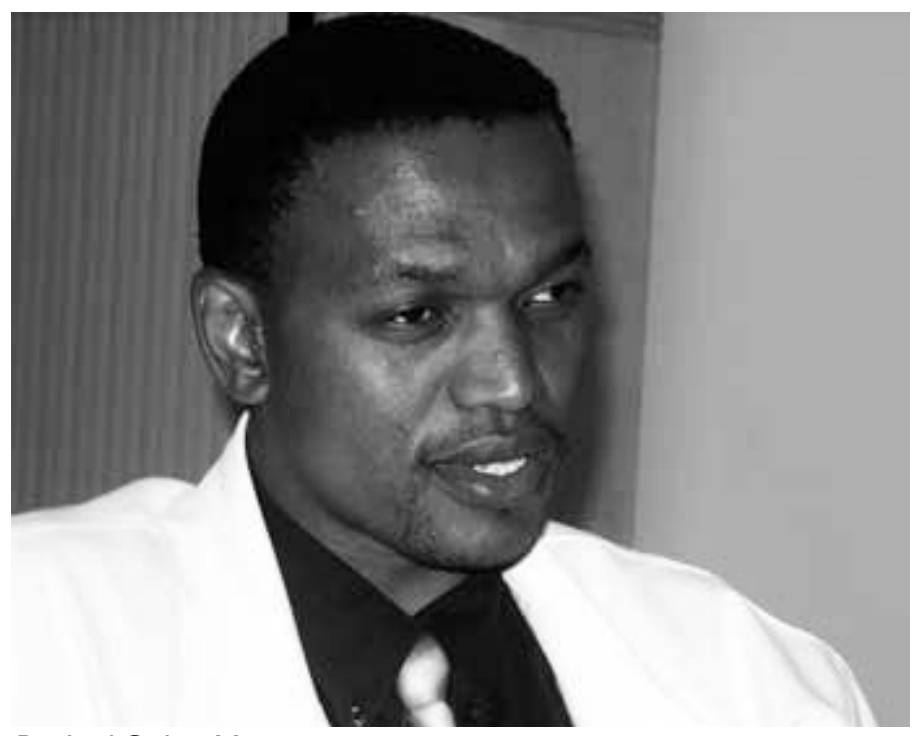

Dr Joel Gcina Mavuso

At 32, Dr Joel Gcina Mavuso is Themba's Medical Manager. But he might be considered an elder in this region, where HIVIAIDS has struck down so many that life expectancy has plummeted to 40. "Ninety-seven percent of the hospital's medical and pediatric beds are filled with patients suffering from HIV-related illnesses," he told MEDICC Review. Of the chronic diseases, hypertension ranks first, followed by diabetes; surgical cases are dominated by stabbings, gunshot wounds, and auto accidents.

Yet the hospital's only specialists are in family medicine, pediatrics, and ophthalmology. "We have 63 physicians, and that includes interns and community service doctors; we need 80," comments Dr Mavuso. South Africa's medical licensing now requires two years of internship and another of community service, where graduates are placed in public hospitals.

The migration of health professionals is a critical problem faced throughout the developing world. They migrate from rural to ur- ban settings, public to private practice, and from their country of origin to the UK, USA, Australia, and elsewhere. In South Africa's case, local personnel are also felled by AIDS, coupling the stress of overwork with emotional burnout. In 2005, there were nearly 46,000 vacant posts for health professionals in the country's public sector.[2] In Mpumalanga, 44\% of the 13,298 posts were vacant and other mainly rural provinces told the same story: Eastern Cape, 27\%; KwaZulu Natal, 30\%; Free State, 41\%.[2]

When it comes to the percentage of physician posts vacant in the public sector, by 2006 Mpumalanga ranked second (38.5\%) after Northern Cape (53.4\%), followed by Eastern Cape (36.1\%).[3] From some South African medical universities, the expatriation rate is as high as 65\%.[4]

Mpumalanga, like other rural provinces, relies in part on foreign doctors, with nine of the permanent staff coming from Cuba, Zimbabwe, Nigeria, Nepal, India, and Zambia. Organizations like The Rural Doctors Association of Southern Africa (RuDASA) have teamed up with The Rural Health Initiative and the Placement Project to bring more developed-country physicians into South Africa's rural public health sector, and most importantly, to attract their South African colleagues back home and back from private practice in the cities.

\section{Long-Term Brain Gain: Turning the Tide}

The so-called brain drain is a complex phenomenon with a web of push-pull factors determining final outcomes. There are no quick fixes. Yet, those on the front lines addressing the critical personnel shortages in South Africa's public health system - especially in rural areas - have pointed to approaches that could slow the exodus and eventually turn the situation around. Cuban cooperation has played and continues to play, a significant practical role in testing these approaches, an experience worthy of documentation and long-term study.

Under a bilateral government accord, in 1997 South African provinces began recruiting primarily black and disadvantaged high school graduates for medical training in Cuba, offering full scholarships to qualified applicants, with the caveat that they return to practice in the public sector for the same amount of time they spent training on the island (five to six years). The program involves one year of pre-med (bridging courses plus Spanish language), two years of basic sciences, and three years of clinical sciences in Cuba. In their sixth year, students return to one of eight South African medical schools for a familiarization period and internship, followed by exams and graduation. As with all other South African medical students, they do a second internship year and a community service year as well.

"The final year in South Africa is important for them," notes Dr Juan J. Ceballos, who coordinates the South African student program in Cuba. "It's there that they practice skills specific to the needs of their country - such as Ceasarian sections, deliveries, and anesthesia - which only medical residents take on in Cuba. In fact, the Cuban family physicians who serve in 


\section{"Brain Gain" Strategies}

The main "brain gain" recommendations emerging from the work of the World Organization of Family Doctors (WONCA), RuDASA, and South African experts such as Drs Steve Reid, David Sanders, Uta Lehmann, Elva DeVries, and lan Couper include:

- Actively recruit for the medical profession among high school students from rural and underprivileged backgrounds, to help them see this as a real option. It has been proven in various countries, including South Africa, that rural-origin students are more likely to remain in rural practice. Dr Steve Reid suggests that social class may be another important factor to consider when recruiting for doctors likely to make their careers in rural public health.[1]

- Offer increased educational and financial support to medical students, with bridging courses where necessary, plus bursaries (scholarships), to keep loan repayment from becoming a barrier to a rural public sector career choice.

- Educate in the spirit of vocation, public service, social responsibility; develop values and leadership in these directions.

- Encourage all medical schools to include more rural medicine courses and clinical teaching in rural settings, making students more sensitive to the needs of rural populations and aware of rural opportunities for practice.

- Redraw the community service program, to assure the neediest hospitals receive community service doctors.

- Ensure adequate mentorship for interns and community service doctors in rural areas; offer post-graduate medical education opportunities for doctors in rural practice.

- Offer financial and other incentives to gain and retain physicians in public, rural facilities where they are most needed.

- Improve career advancement opportunities for physicians in the rural public sector.

- Train physicians as team players, able and willing to work with other health professionals in effective multidisciplinary teams at the local level.[2-6]

\section{References}

1. Reid S. New Perspectives on an Old Problem: Recruitment and Retention of Health Professionals in Rural Areas. Plenary Address to the 11th Rural Doctors of Southern Africa conference; 2007 Aug 24; Badplaas, Mpumalanga [cited 2007 Dec 15]. Available from: http://www. rudasa.org.za/conference/conf11/plenary.pdf

2. Lehmann U, Sanders D. Human Resource Development. In South African Health Review 2002. Durban: Health Systems Trust; 2002. p. 119-133.

3. De Vries D, Reid S. Do South African rural origin medical students return to rural practice? In Health Systems Trust 2003. Durban: Health Systems Trust 2003 [cited 2007 Dec 10]. Available from: ftp://ftp.hst.org.za/pubs/research/ruralorigin.pdf

4. Mapham W. Vice President, Rural Doctors Association of Southern Africa (RuDASA), Personal communication. November 14, 2007.

5. Crisis in Staffing of Rural Hospitals. RuDASA Position Paper, January 2001 [cited 2007 Dec 15]. http://www.rudasa.org.za/download/crises_staffing. doc

6. Health for All Rural People: The Durban Declaration, 2nd World Rural Health Congress, 1997; Durban: WONCA [cited 2007 Dec 15]. http://www. rudasa.org.za-download-durbandec.pdf.url

South Africa also have to acquire these skills before practicing there, where they might find themselves the only doctor within miles."

Over 400 South African students are now in the program, and another 88 have graduated thus far.[5] "They come to us educationally better prepared than the average international medical student in Cuba," comments Dr Ceballos. "Where is our contribution, besides the medical-scientific training per se? I think over the years in Cuba, their self-esteem is bolstered; and I've seen that the curriculum's emphasis on public service and the right to health care also has an influence."
Thenjiwe Mtintso, South Africa's Ambassador to Cuba, concurs: "South Africa not only needs doctors - young people with skills but also needs young people ready to do service for their people and communities, to fulfill Mandela's call to be 'servants of the people.' Studying in Cuba exposes the South African students to a country dedicated to service and doctors who see themselves as servants to others."

Dr Ayanda Ntsaluba, Director General of Health when the Cuban-South African agreement was signed over a decade ago, notes that South African policymakers were also attracted to the Cuban emphasis on prevention, primary care, and the bio-psycho-social approach that views patients holistically. The team focus also made a difference, says Ambassador Mtintso, "In Cuba, you do not find a serious hierarchy in the way the doctors and nurses relate to each other; they work together."

Expectations of the graduates are high. "These graduates have to be pioneers for change in South Africa's approach to health care," says Ambassador Mtintso. A tall order, and one that makes tracking their experience all the more important. Where are the first ones now? How have they fared thus far?

MEDICC Review returned to Mpumalanga's Themba Hospital to find five of them - four

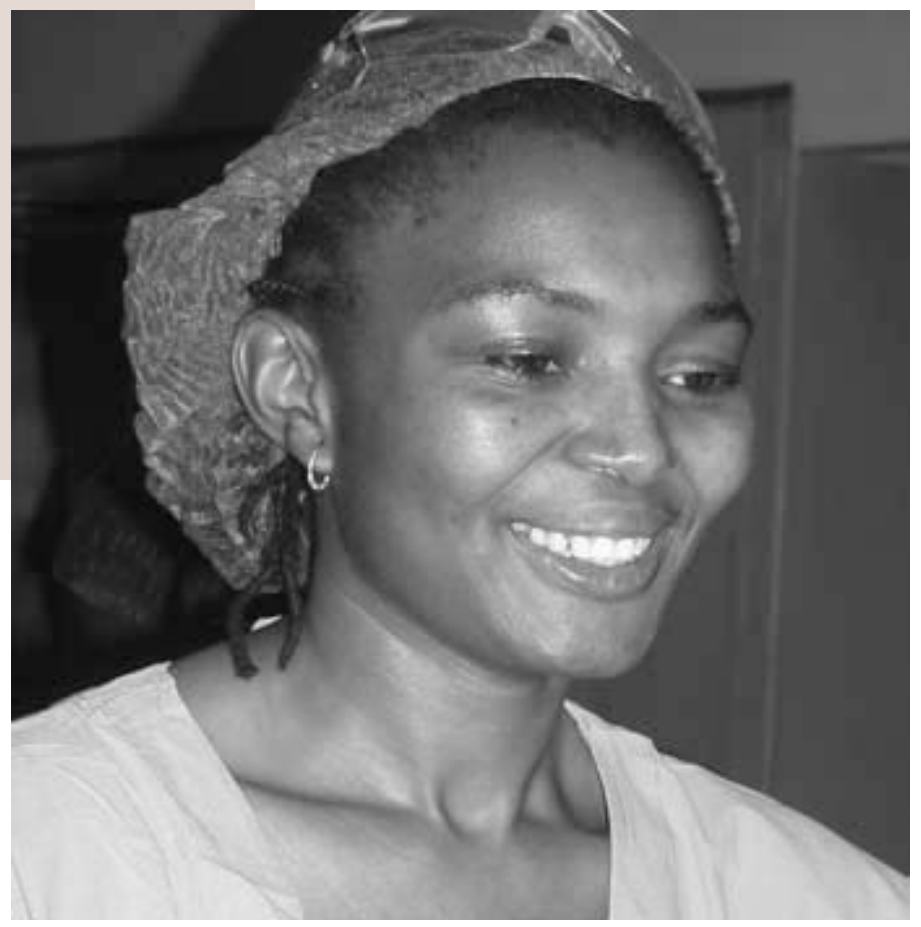

Dr Thobile Msithini 


\section{International Cooperation Report}

South African graduates, and one from Swaziland who also received his degree in Cuba. Like the Medical Manager Dr Mavuso, they are primarily from the more rural provinces: Dr Emmanuel Shabangu, in community service, comes from KwaZulu Natal; Dr Charles Mlapa, an intern, is from North West province; Dr Mandla Sibandle, a Senior Medical Officer, comes from Mpumalanga itself; and Dr Thobile Msithini, a Medical Officer and the only young woman in the group, is from KwaZulu Natal as well. Dr Gabriel Mkhumane, from Swaziland, is also serving as a Medical Officer.

"I receive excellent support from the Cuban-trained physicians," says Dr Mavuso. Like all doctors at the hospital, Mavuso and the rest receive the $15 \%$ scarce-skills salary bonus for working in a rural area. And they have a mentor in Dr Elpidio López, a Cuban specialist in family medicine, who has been at the hospital for the last 12 years, and lives in White River with his wife and two daughters.

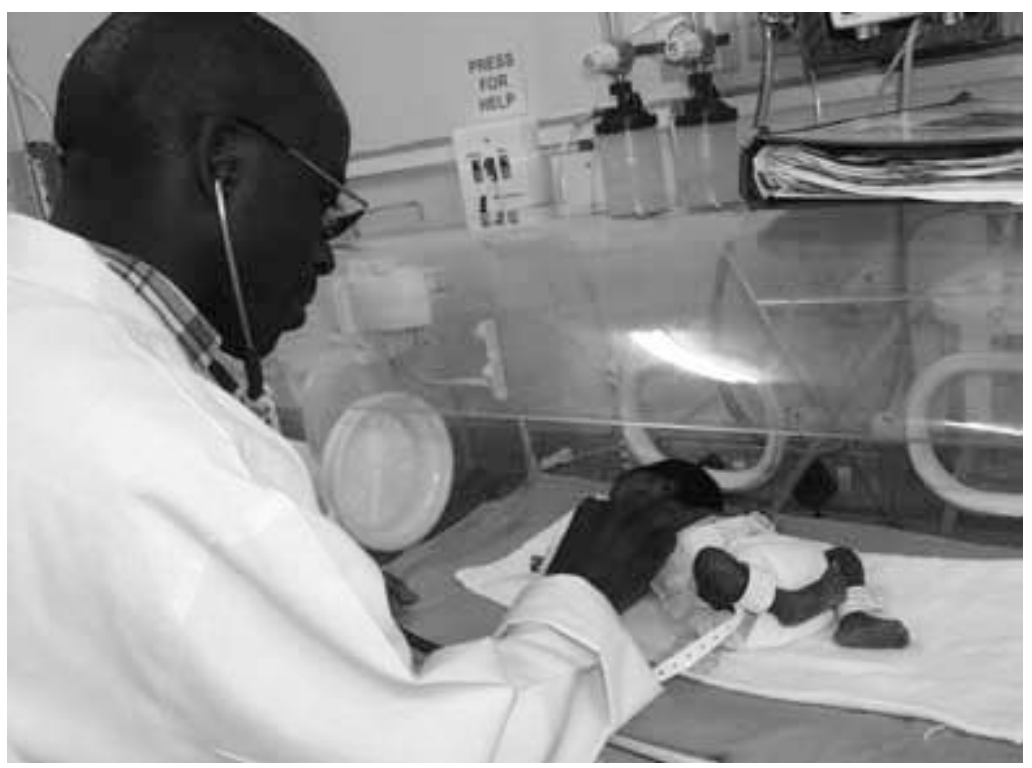

Dr. Emmanuel Shabangu

Mentorship is a key component of practice for young physicians at a hospital that receives $250-300$ outpatients daily, to say nothing of casualties. "Sometimes it's overwhelming," says Dr López. "We've had to suture 12 gunshot wounds in one day; and last Christmas, we had 75 stabbings. When you need to send a patient elsewhere, the other hospital will often answer that they are full up. If it weren't for the fact that we work as a team, it would be impossible."

The team approach they learned in Cuba was also mentioned by each of the graduates as one factor that would keep them at this hospital over time: "we know we can count on each other," says Dr Sibandle, who works in the Bambanani outpatient program for HIVIAIDS patients. "We have more than 2,000 patients in the program, and that means 40 people a day per doctor."

Getting to this point in their careers was not easy. Several of the Cuban-trained graduates said they faced racism and prejudice at some South African medical schools when they returned home for their sixth year of training. They also had to learn additional country-specific skills and medical English. "In addition," says Dr Sibandle, "we had to reintegrate into the South African health system, and get to know the diseases we would face daily...In Cuba, it was a different setting; the AIDS patients we saw there looked normal."

Nevertheless, these graduates say they feel "at home" in the rural setting. "This is where I want to be," says Dr Msithini through the glass as she steps out of the orthopedic surgery unit, a sentiment echoed by the others. "You feel terribly needed here. We're here for our patients...even when they come in so late that it makes it difficult to save them," comments Dr Mlapa.

But will they stay to help transform health care in rural South Africa? This is a question Dr Mavuso and even the Cubans are asking themselves. "One problem right now," he says, "is that it's very difficult for young doctors to move up the career ladder here; and also difficult for them to study."
"We want to continue to support them past their initial commitment to rural public service," notes Dr Tomas Reinoso, who heads the 147-member Cuban medical team serving in South Africa. Next on his agenda? Working to make a family medicine residency possible at Themba. He raises this with the graduates, and they are keen on the idea - even knowing it would mean another three years at this hospital.

It's clear that thus far, the Cuban-South African education model incorporates many of the "brain gain" recommendations defended by South African and international experts (see box); other policies are up to local authorities and institutions. Eighty-eight new medical doctors have graduated from the program; there are an additional 422 to go. Another joint effort to evaluate their progress is surely in order, as this experience carries implications for the entire Global South. 1 -

\section{References}

1. Richmond S, et al. Mpumalanga. In: South Africa, Lesotho \& Swaziland. Victoria. Australia: Lonely Planet; 2002. p. 438.

2. Total number of health professional posts [homepage on the Internet]. Durban: Health Systems Trust; 2007 [cited 2007 Dec 10]. Available from: http://www.hst.org.za/healthstats/133/data

3. Percentage of medical practitioner posts vacant, 2006 public sector [homepage on the Internet]. Durban: Health Systems Trust; 2007 [cited 2007 Dec 10]. Available from: http://www. hst.org.za/healthstats/255/data

4. Reid S. Community Service for Health Professionals. In: South African Health Review 2002. Durban: Health Systems Trust; 2002. p. 135-160.

5. Personal interview with Dr Juan J. Ceballos, Havana, November 15, 2007.

Photos by Gail Reed 